\title{
The Ejido-system in Mexico; some observations
}

\author{
R. A. L. LINCKLAEN ARRIËNS
}

Department of Agricultural Economics of the Tropics and Sub-tropics, Agricultural University, Wageningen, The Netherlands

\section{Summary}

A brief outline is given of the economic development of Mexico and the contribution of agriculture to it. After a sketch of the historic background of the land reform program and he ejido-system some data are given with regard to the operation of it and the land tenure situation. An effort is made to give an appraisal of the land reform program and an evaluation of the results. It cannot be denied that the agrarian reform indirectly stimulated enterprise in industry and commercial agriculture. Although the agricultural product per worker doubled in the last 2 decades, the gross agricultural product tripled in the same period, while at present the working population engaged in agriculture amounting to $50 \%$ of the total working population, only contributes $20 \%$ to the national product. On the ejidos the production per worker and per ha are much less than the average.

Also from two regional investigations the conclusion can be drawn that the ejido farm is inferior to the private farm due to poor educational level, farming techniques and capital resources, smallness of plots and weak structure and functioning of the ejido as an organization.

In the last paragraph some conclusions and comments are presented. It seems that too much value has been attached to the land tenure aspects and the legal regulations and too little to the creation of opportunities for efficient farming.

The promotion of more variation in types and sizes of farms and in the land tenure pattern might lead to more alternative opportunities, commercialization and increased productivity and to more diversification and integration of the rural economy.

\section{Introduction}

Having participated in the XIth International Conference of Agricultural Economists held in Aug. '61 in Mexico, the author had an opportunity to gather personal impressions and informations on the land reform program in operation in this country during the last half century.

Thanks to the Mexican authorities and the Dutch agricultural attaché and after studying some Mexican and other publications on the subject he could form a rough picture of the ejido-system which led him to the following observations.

\section{Background information}

\subsection{Ge ner a l}

Mexico is a vast country with a great variety in regions, landscapes, soils and cliReceived for publication 25th January, 1962. 
mates due to its rugged topography and its latitude between the $14^{\circ}$ and $32^{\circ}$ parallels. It covers nearly $200 \mathrm{mln}$ ha (nearly $60 \times$ The Netherlands) and is inhabited by 34 mln people $(3 \times$ The Netherlands) with an annual rate of growth of over $3 \%$. (The Netherlands $1,5 \%$ ).

It is a fascinating country which exhibits a certain exotic greatness, dating back to Spanish, Aztec and pre-Aztec cultures. It is also a country of contrasts. Contrasts between dry and wet, high and low, hot and cool and between poor and rich. Its socio-economic growth is vigourous but uneven.

"In summary, one might state that Mexico's economic and social policy has not been characterized by perfect continuity but rather gives evidence at times of divergent conceptions in its outline and execution" (14) (see TABLE 1).

TABLE 1.

\begin{tabular}{|c|c|c|c|c|}
\hline \multirow[t]{3}{*}{ Years } & \multicolumn{4}{|c|}{ Population in mlns } \\
\hline & Total & $\begin{array}{l}\text { Economically } \\
\text { active (total) }\end{array}$ & $\begin{array}{l}\text { Economically } \\
\text { active in pri- } \\
\text { mary activities } \\
\text { (agriculture) }\end{array}$ & $\begin{array}{l}\text { Proportion } \\
\text { (c) : (b) in \% }\end{array}$ \\
\hline & (a) & (b) & (c) & \\
\hline 1930 & 16,6 & 5,2 & 3,6 & 71 \\
\hline 1940 & 19,7 & 5,9 & 3,8 & 65 \\
\hline 1950 & 25,8 & 8,3 & 4,9 & 58 \\
\hline 1960 & 34,6 & 11,4 & 6,0 & 53 \\
\hline
\end{tabular}

Note: Data derived from (6).

The urban population shows a much faster increase than the rural population. From 1930 to 1960 the first category increased from 5,5 to $15,7 \mathrm{mln}$; the second from 11 to $18,9 \mathrm{mln}$ (6). More than $50 \%$ of the economically active population is engaged in agriculture, contributing $20-25 \%$ of the national product. The percentage of agricultural workers, although decreasing, seems still to be rather high, the proportion to the national product too small in relation to the stage of economic development Mexico has reached. It should be taken into account however that there is much disguised unemploment in agriculture. Roughly $1 / 3$ of the agricultural population works only 5 months per annum in agriculture proper. The remainder of the time many of them work elsewhere in all sorts of jobs (6). There exists a seasonal movement of agricultural laborers to the U.S.A. which relieves the population pressure in the central zone.

Much progress has been made in economic development although much more might be achieved especially in the agricultural sector where the average per capita income is less than $1 / 3$ of that in other sectors of economic life.

Gross national product based on prices of 1950 rose from 20,7 bln $^{1}$ pesos in 1940 to $41,5 \mathrm{bln}$ in 1950 and $67 \mathrm{bln}$ in 1960 (8). National income per capita in real terms however was in 1959 only $5 / 3$ of that in 1940 (14).

\subsection{Agriculture and economic development}

The arable land amounts to $20 \mathrm{mln}$ ha. Actually cultivated is $55 \%$ of this area of which $80 \%$ is being harvested (The acreage harvested has increased from $6,2 \mathrm{mln}$

1 "bln" means $1000 \mathrm{mln} ; 1$ peso $=$ Dfl. 0,30 . 
ha in 1946 to $10,5 \mathrm{mln}$ ha in 1955). Of the various crops maize is predominant. Rainfall is the critical climatic factor for agriculture, since $4 / 5$ of all arable land is "temporal" or seasonal. Good soils are not abundant. There are large zones of sandy or stony soils lacking organic material. Other handicaps are salinization and erosion.

The development of agriculture within the country's economy can best be demonstrated by the following figures derived from table 33 in (6) (The figures of Gross National Product differ from those published by the Banco de Mexico) (see Table 2).

TABLE 2. Gross products based on 1950-prices in blns pesos

\begin{tabular}{cccc} 
Year & \multicolumn{2}{c}{ Gross product } & $\begin{array}{c}\text { Proportion } \\
(1):(2) \text { in } \%\end{array}$ \\
\cline { 2 - 3 } & $\begin{array}{ccc}\text { Agricultural } \\
\end{array}$ & National & \\
1930 & 2,9 & $(2)$ & \\
1935 & 3,2 & 9,4 & 31 \\
1940 & 5,0 & 12,9 & 25 \\
1945 & 6,0 & 21,5 & 23 \\
1950 & 8,9 & 32,1 & 19 \\
1955 & 12,1 & 43,3 & 21 \\
1959 & 15,2 & 57,7 & 21 \\
& & 70,9 & 21 \\
\hline
\end{tabular}

In the last 2 decades, during which the population rose by $75 \%$, the total agricultural production tripled as a result of an increase of the area harvested of $100 \%$ and an increase of yields per ha of $50 \%$. The National Product increased still more than the Agricultural Product.

Mexican agricultural policy tries to develop the agricultural economy along three basic lines (15):

1. The production of basic foods for a growing population seeking to improve its diet;

2. The efficient production of raw materials for the developing agriculturral industries ;

3. The augmentation and diversification of export products of competitive quality on the international market.

On the domestic market a government-sponsored marketing organization controlls to some extent marketing and prices of agricultural produce with the purpose of stabilizing prices, ensuring to the farmer an adequate return and to the consumers moderate prices.

It appears that in 1955 the average value of crop production per ha was around 1000 pesos. The industrial and export crops however yield a much higher value per ha, the foodcrops for domestic consumption a much lower one. Broadly speaking the first category produced a value of 2000 and the second of 500 pesos per ha (13). Of the total area under cultivation of around $10 \mathrm{mln}$ ha more than $50 \%$ is devoted to corn, the hasic food. Beans, also an important food item make up $13 \%$ of the area. In wheat, harvested on $7 \%$, the country has now become self-sufficient. Sugar cane is grown on $2,5 \%$. Cotton, the major export crop, occupies nearly $1 \mathrm{mln}$ ha or $10 \%$. Coffee, the second export crop is grown on $2,5 \%$. Henequen, rice and 
vegetables each cover $1,5 \%$. Of the vegetables tomatoes, garlic, chile and onions should be mentioned, of which tomatoes are being exported for $1 / 3$ of the total production and garlic for $45 \%$. The principal fruits are oranges, plantains and other bananas, grapes and coconuts. Around $10 \%$ of the first 2 kinds enter foreign trade. Fruit orchards occupy $1,5-2 \%$ of the cultivated area (14).

More diversification of produce has been achieved in so far that commercial crops have been extended.

Animal production also increased considerably. Livestock represented $25 \%$ of the agricultural product in 1959 (4).

The share of agriculture in exports is also increasing, which is very satisfactory since domestic consumption already puts a heavy drain on it (the population growth is $3 \%$ per year) (TABLE 3 ).

\begin{tabular}{cccc} 
TABLE 3. & Export structure in mlns of & 1955 dollars (4) \\
\hline Year & Total exports & $\begin{array}{c}\text { Agricultural } \\
\text { and forestry } \\
\text { products }\end{array}$ & $\begin{array}{c}\text { Livestock and } \\
\text { fish products }\end{array}$
\end{tabular}

$\begin{array}{llll}1941 & 391 & 113 & 47 \\ 1949 & 490 & 221 & 43 \\ 1959 & 930 & 566 & 76\end{array}$

Unprocessed goods (raw materials) continue to occupy the leading position, which makes exports vulnerable because of the fluctuations of world market prices.

Agricultural exports make up $50-60 \%$ of total exports.

In 1960 agricultural exports amounted to nearly 5 bln pesos while agricultural imports valued only 1,4 bln pesos. These figures demonstrate the importance of agriculture for the balance of trade which has been negative for many years. This could be only compensated by tourism, remittance of Mexican workers in the U.S. and foreign loans for economic development (TABLE 4).

TABLE 4. Exports and imports in mlns US dollars

\begin{tabular}{ccc}
\hline Year & Exports & Imports \\
1953 & 559,1 & \\
1955 & 738,6 & 807,5 \\
1957 & 706,1 & 883,7 \\
1959 & 723,0 & $1.155,2$ \\
& $1.006,6$ \\
\hline
\end{tabular}

Note: Data derived from (14).

Industrialization has not yet gone far enough to absorb all excess rural workers with the result that there are many rural people living on a submarginal or subsistence level or that they are umemployed.

Visiting the rural regions in the central part of Mexico one is struck by the great contrasts between the level of living here and in the industrialized centres in or near the cities, where much of the profits apparently are being accumulated by a relatively small number of people.

The majority of urban workers suffers from increasing costs of living. The worker's cost of living index in Mexico City shows an increase from 100 in 1939 to 700 in 1959.

Costs of food index figures in Mexico City $(1954=100)$ indicate the same trend $(20,8$ in $1940,70,5$ in 1950 and 151,7 in 1960$)$.

Index figures of wages are not at hand. 


\section{Agrarian history}

One cannot gain a clear understanding of Mexico's agrarian problems without some knowledge of their historic background. As is justly put in Nathan WhetTen's book (22), "much of Mexico's agrarian history revolves around the struggle for supremacy between the landholding village and the large, privately owned, semifeudal, landed estate, commonly referred to as the "hacienda"."

The Aztec empire already had its landholding villages. Each village had its surrounding town land or "altepetlalli" ; each clan its clanland or "calpulalli". The agricultural land of the latter was distributed in individual plots among the clan members (heads of families). Gradually lands were set aside for the officials, for the maintenance of warriors, or for the use of the priests. Originally these lands were tilled in common by members of the clan but gradually by serfs for the benefit of developing classes of priests and nobles. In this way landed estates with serfs "bound to the soil" developed.

Later on the Spaniards, who were familiar with both the landholding village and the individual landed estate, ordered the granting of common land to the settlements of New Spain.

Gradually the "calpulalli" lost significance and the term "ejido" was applied to the "altepetlalli" or common village-land. The word "ejido" stems from the latin "exitus" and means the lands situated at the exit of a village.

"In this manner a Spanish institution analogous to ancient Aztec institutions was transplanted, thereby reviving the tradition of the inalienable common ownership of the land which served as refuge and economic prop for the peasant against the expansion of the latifundia" (4).

The protection of the village land however, has been "strangled" by other measures viz. the allotments of one or more villages to persons who had distinguished themselves in Christianizing Indians and bringing them under the Spanish crown. It is quite understandable that this procedure gradually led to feudalistic large estates where the beneficiary regarded the area assigned to him as his personal property and the inhabitants as his serfs. Besides there was a scheme to straighten out titles on land and to discover public lands held illegally. Although the rights of the Indians should be protected, many landowners abused the various measures to their advantage (e.g. to confirm possession of lands occupied illegally) while the Indians did not understand and did not use the opportunity to have their lands legally confirmed.

Although also in the colonial period various efforts were made to protect and stimulate agricultural development of village lands the results have rather been opposite.

The various kinds of landed property always faced the threat of "latifundist voracity" and gradually fell victim to annexation by the large land holdings. This went so far that in 1910 only $3 \%$ of the heads of families owned landed property. In that same year the revolution broke out and the peasants, starving and in desperation, joined the rebel party and rose up in arms under the cry of "Tierra y Libertad" (Land and Freedom). The revolutionary movement was carried forward to victory which led to the returning of the lands to the peasants through the expropriation of latifundia (large estates).

The revolution thus was a reaction to the monopolization of the lands that began with the Spanish conquest, creating a system of latifundia owned by an elite class and leaving the majority of the rural population as an underprivileged group put 
to the mercy of the first. The Agrarian Reform freed the labor of the peasant from its bonds and gave the rural peopie again a social status with equality of rights for everybody.

\section{Land Reform}

\subsection{Legis 1 at ion}

After the foregoing it will be understood that the Agrarian Reform is the outstanding feature and the basis of all agrarian development since the revolution of 1910. Its principles are laid down in Article 27 of the Mexican Constitution: The ownership of all lands and waters belongs to the Nation "which has the right to transmit title thereof to private parties, thereby constituting private property". Expropriation may be carried out only for reason of public benefit and with compensation. The nation has the right to impose measures upon private property dictated by public interest and to regulate the utilization of natural elements to achieve a more equitable distribution of the public wealth and to insure their conservation. Measures for breaking up latifundia will be decreed: for the development of small agricultural properties, for the establishment of new agricultural population centres, for the development of agriculture and to prevent destruction of natural resources (4). Population centers lacking land or water have the right to be supplied with these to be taken from adjacent properties, always respecting small agricultural holdings under cultivation.

So the two basic principles of the "re-integration of national property" are: the rights of the rural communities to have lands (ejidos) and the safe-guarding and encouragement of all small holdings under cultivation.

In order to qualify for a land-grant the village, claiming the land, must be located within a radius of $7 \mathrm{~km}$ of the property to be expropriated and at least 20 native born Mexicans of that village or community must submut a request. The Department of Agrarian and Colonization Affairs hears evidence from the landowners and from the claimants; the final decision is made by the President of the Republic (12).

\subsection{Ceilings of private holdings}

The maximum limits of inaffectible private holdings are 100 ha of irrigated or humid land, 200 ha of non-irrigated land, 150 ha of cotton, 300 ha of bananas, sugarcane, coffee, cacao, fruittrees, henequen and a few other perennial crops, or the amount of land required to maintain 500 head of cattle. The owner is allowed to choose the land he is permitted to retain. The excess part is turned over to the requesting community as an "ejido".

In the beginning there was a tendency to restrict exproporiation to the less efficient haciendas and in the early thirties there was even a drastic decline in the land distribution program, because Mexico's "boss", President Calles, became of the opinion that the peasants well-being could not be assured by giving them a patch of land if they lacked the preparation and elements to cultivate it. Within a short period the program should be terminated and "then guarantees (should) be given to everybody, little and big agriculturists (alike) so that initiative and private and public credit could be revived" (22).

President Lázaro Cárdenas on the contrary was convinced that the ejido-system should be extended, as the ejido should be "a fundamental part of the national economy" 
(22). Hence during the Cardenas-period (1935-1940) more land has been distributed than in all previous years. Even well operated economically efficient haciendas were expropriated although it probably would have been more profitable to leave these to the owners and only enforce better wages and working conditions for the laborers (if practicable).

There have been various abuses in the carrying out of the land-reform program, both on the side of the haciendados and by the agrarians and also by politicians and Government officials, but gradually procedures were improved and abuses eliminated.

One of the serious shortcomings was that "no studies were made for different regions to indicate the number of ha of the various types of land necessary to support a family", nor that any attempt was made "to organize regional areas into logical producing units or to adapt the size of holding to the type of crop to be produced" (22).

Where new villages or communities have been established hardly any advantage has been taken of the opportunity to introduce improved systems of village arrangements including sanitary measures, housing and farm construction. Although the lack of planning has been admitted, the argument has been that one had to push through while conditions were favorable, even without technical plans.

\subsection{Redistribution of 1 ands}

The redistribution of land has taken place in different ways (12):

1. through grants a. to restore to a community lands which formerly belonged to it, b. without requiring evidence of former ownership of the land by the community (the latter type became the most important one) or c. to extend a previous grant which proved to be insufficient for the needs of the community;

2. through the establishment of new centres of population in cases where there is no land subject to expropriation within the $7 \mathrm{~km}$ radius (in such cases the land claiming group may be transported to another place where land is available);

3. through land settlements under the law of Colonization (under this law agricultural colonies may be established on rural land, national or private provided that this land is not already used for agricultural production, does not belong to the forest reserves and is not exempted from expropriation).

The "Departemento de Asuntos Agrarias y Colonizacion" offers special inducements to those peasants who so far could not get a piece of land because the land grant was not sufficient to cover the requirements of all peasants involved. These people have so-called "derechos a salvo" or reserved rights. After being transported to the area to be settled the peasants receive some financial and other support and the land is sold to them below market price. After completing their payments the settlers receive full title as private owners of the land.

In the case of new settlements as "ejidos" the settlers after repayment of expenses to the Government are given limited possession of the land (the land is given to the village; individual plots cannot be sold or mortgaged) but free of charge.

It has repeatedly been stressed that the redistribution of land is not the only aspect of the Agrarian Reform. The latter includes irrigation works, improvement and extension of communication and transport, agricultural research, education and extension, credits, the use of fertilizers, pest control etc. Although many results have been 
claimed, it seems that at least in some regions much more could be achieved. It is usually argued that to develop agriculture and improve agricultural production much more funds are needed and that these funds are not sufficiently made available.

At present the Department of Agrarian and Colonization Affairs is in charge of the distribution of land under the ejido and colonization programs and also of promoting agricultural and livestock production in these settlements including the development of complementary industrial activities.

It also examines the concessions of livestock inaffectability (made for a period of 25 years, which may be renewed). The concessions will be respected if concessionaires are using the land as required by the law. Also small private agricultural holdings within the limits of the agrarian legislation are being respected (12).

Lands held by ejidos are well distributed over the country although with a rather wide variation. In the central part $45 \%$ is held by ejidos; in the State of Morelos more than $80 \%$; in the Northern parts with its arid climate only $15 \%$.

\section{The ejidos}

At present the term "ejido" refers to an agrarian community which has received land in accordance with the agrarian laws; the term "ejidatario" to an individual who has participated as a beneficiary in a grant of land in accordance with the agrarian laws. "The totality of ejidatarios participating in a given grant, together with their families and the lands which they received, constitute an ejido" (22). Usually there are around 100 families on an ejido with the exception of the central region where there are ejidos of more than 200 families.

Each ejido is a legal and democratically run organisation. "Ultimate local authority is vested in the general assembly, with administrative functions delegated to 2 local committees", a sort of executive committee and a vigilance committee, each of 3 elected members.

Full particulars of the ejido system and the rural situation can be found in (22).

Rules of tenure. Pasture- and wood lands belong to the ejido collectively; the same applies to the right to use irrigation water.

The tillable land can be farmed collectively or individually. If the latter is the case (the majority) the arable land is divided into plots, one for each ejidatario, which he may use all his life and pass on to his heir (only one).

The right of the ejidatario, either to participate in the collective enterprise (collective farming) or to use his plot individually (individual farming) cannot be alienated or transferred to another, nor can the land be leased or mortgaged either.

For their housing the ejidatarios can obtain full individual ownership of their houselots (after some years of continuous possession).

Ejido lands. Nearly $45 \%$ of all arable land of $20 \mathrm{mln}$ ha is in ejidos. The total of all ejido lands is $39 \mathrm{mln}$ ha including pastures, woodland and land not suitable for agriculture.

In fixing the area of each parcel of the "ejidatarios" the directives have changed over the years. In the beginning the size should be such that the income derived from it should be the double of the annual wage income in the region. As the 
application of this rule was too difficult, the area of each parcel was fixed at 3 ha irrigated and 6 ha seasonal land. This size was gradually increased. In recent years the aim is 10 ha and $20 \mathrm{ha}$. The average for the whole country is 6 ha arable land (with a wide variation) (4). There is no strict rule for pasture- and woodlands.

At present the total number of settlements definitively granted ejidal lands amounts to over 18.000 (4) of which more than $50 \%$ were established in the decade 19301940. The number of peasants who benefited is $2 \mathrm{mln}$; the total area distributed amounts to $45 \mathrm{mln}$ ha (estimated).

Irrigation. The total irrigated area in 1960 comprises $4 \mathrm{mln}$ ha, of which $1,7 \mathrm{mln}$ ha through irrigation works built in former times, and $2,3 \mathrm{mln}$ ha thanks to activities of the Mexican Government since 1928. In the new irrigation districts farming has improved considerably; crops grown on irrigated lands make up nearly $50 \%$ of the total value produced (4).

Much emphasis is rightly laid on the importance of irrigation (both by using surface water and through pumping up of subterranean water). It seems however that the financial burden for the Government is severe. Proper distribution of costs and benefits will require careful examination. It would be beyond the scope of these "observations" however to go into this matter.

In the National irrigation districts it was provided that whenever the ejido requirements were fulfilled, the major part of the remainder would be divided up into parcels varying from 8 to 100 ha. These were sold to farmers on long terms and at low interest rates, which under prevailing favorable conditions probably provides the best basis for efficient farming.

\section{Land tenure situation}

The following figures summarize the land tenure situation according to the 1950census (data of the 1960-census are not yet available):

Number of ejidos

Number of ejidatarios with land $\ldots \ldots \ldots \ldots \ldots \ldots$

Number of private holdings $\ldots \ldots \ldots \ldots \ldots \ldots \ldots$

of which of 5 ha and less

1.004 .800

Total area of which in ejidos $145,5 \mathrm{mln}$ ha

in private holdings

$38,9, "$, of which of 5 ha or less

$106,6, "$,

Total area cultivated

$1,4,,$,

of which in ejidos

$10,9, "$,

in private holdings

$5,3, "$,

of which of 5 ha or less

$5,5, "$,

$0,9, "$,

The classification of lands is shown in TABLE 5 .

The area harvested is comparatively small. In mlns ha we find:

$\begin{array}{rcccc} & & 1930 & 1940 & 1950 \\ \text { Area harvested } \ldots \ldots \ldots \ldots \ldots \ldots & 5,9 & 6,7 & 8,6 \\ \text { of which ejidal } \ldots \ldots \ldots \ldots \ldots & 0,8 & 3,3 & 4,0 \\ \text { private } \ldots \ldots \ldots \ldots \ldots & 5,1 & 3,4 & 4,6\end{array}$


THE EJIDO-SYSTEM IN MEXICO; SOME OBSERVATIONS

TABLE 5. Classification of lands in min ha (1950)

\begin{tabular}{|c|c|c|c|}
\hline & Total area & Non-ejidal & Ejidal \\
\hline Total & 145,5 & 106,6 & 38,9 \\
\hline Arable lands $\ldots \ldots \ldots \ldots \ldots$ & 19,9 & 11,1 & 8,8 \\
\hline irrigated $\quad \ldots \ldots \ldots \ldots \ldots$ & 2,4 & 1,2 & 1,2 \\
\hline humid & 0,7 & 0,3 & 0,4 \\
\hline seasonal & 16,0 & 9,1 & 6,9 \\
\hline with fruittrees and crops & 0,8 & 0,5 & 0,3 \\
\hline Grasslands $\ldots \ldots \ldots \ldots \ldots \ldots$ & 67,4 & 50,8 & 16,5 \\
\hline Woodlands & 38,8 & 30,0 & 8,8 \\
\hline$\ldots \ldots \ldots \ldots \ldots$ & 7,8 & 6,1 & 1,7 \\
\hline Weste land. & 11,6 & 8,5 & 3,1 \\
\hline
\end{tabular}

Note: Data derived from (4).

Of the 1.365 .600 private holdings about $1 \mathrm{mln}$ measure 5 ha or less, 295.000 are $5-100$ ha, 55.000 have an area of 100-1000 ha and 10.000 of over 1000 ha.

The fact that there are more than $1 \mathrm{mln}$ private holdings of less than 5 ha reveals the existing landhunger of the peasants (including ejido members).

\section{Investments and Credits in Agriculture}

It stands to reason that the Government, being fully aware of the importance of agriculture in the country's development, is trying to promote agriculture technically and economically, among other things by stimulating investments and credits.

It has been estimated that $50 \%$ of the agricultural investments in recent years has come from private sources; more details are not at hand.

Public investments in agriculture were substantial although a larger share might be expected as compared with other underdeveloped countries, where these investments amount to $25 \%$ of the total investments (see TABLE 6).

Table 6. Public investments in mln pesos and percentages

\begin{tabular}{ccccccc}
\hline Year & $\begin{array}{c}\text { Total } \\
\text { (min pesos) }\end{array}$ & \multicolumn{2}{c}{ Agriculture } & \multirow{2}{*}{$\begin{array}{c}\text { Transport } \\
\%\end{array}$} & $\begin{array}{c}\text { Electricity } \\
\text { Oil industry }\end{array}$ & $\begin{array}{c}\text { Other } \\
\%\end{array}$ \\
\cline { 3 - 4 } & & $\begin{array}{c}\text { Irrigation } \\
\%\end{array}$ & $\begin{array}{c}\text { Other } \\
\%\end{array}$ & & & \\
1940 & 336 & 10,7 & 2,4 & 45,2 & 18,2 & 23,8 \\
1945 & 953 & 14,7 & 0,8 & 47,8 & 13,6 & 23,0 \\
1950 & 2.666 & 14,0 & 6,8 & 40,9 & 23,8 & 14,6 \\
1955 & 4.660 & 13,1 & 0,1 & 31,9 & 30,6 & 24,4 \\
1959 & 7.130 & 10,0 & 0,6 & 39,1 & 27,7 & 22,6 \\
\hline
\end{tabular}

Note: Data derived from (6) p. 360.

Main public investments in agriculture have been in irrigation works. Only very little has been invested in other respects (research, education, extension, soil conservation etc.). 
Of Federal expenditures of 6,7 bln pesos in 1960

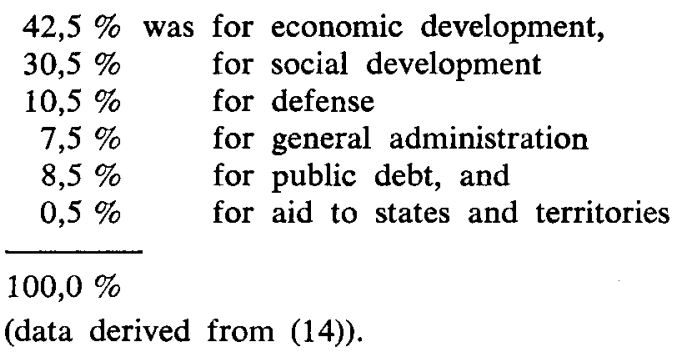

In $195649 \%$ was devoted to economic and $22,5 \%$ to social development. So in 1960 emphasis has been shifted from economic to social issues. Within the economic development sector in 1946 agriculture and irrigation had priority. From 1951 to 1958 attention shifted to communications and in 1959 to education (14).

As to agricultural credits the figures in TABLE 7 can be given.

TABLE 7. Agricultural credits; balance at the end of each year

\begin{tabular}{cc|cc|c}
\hline Year & $\begin{array}{c}\text { All banks } \\
(\mathrm{mln} \text { pesos) }\end{array}$ & $\begin{array}{c}\text { National } \\
\text { institutions }\end{array}$ & $\begin{array}{c}\text { Private } \\
\text { institutions } \\
\%\end{array}$ & $\begin{array}{c}\text { National } \\
\text { Ejido Bank } \\
\%\end{array}$ \\
1943 & 529 & & 29,1 & 31,6 \\
1945 & 584 & 70,9 & 40,6 & 25,3 \\
1947 & 708 & 59,4 & 24,3 & 27,5 \\
1949 & 916 & 75,7 & 30,7 & 25,6 \\
1951 & 1252 & 69,3 & 41,5 & 20,0 \\
1953 & 2053 & 58,5 & 32,2 & 15,7 \\
1955 & 2807 & 67,8 & 35,9 & 16,6 \\
1957 & 3605 & 64,1 & 35,0 & 22,2 \\
1959 & 5036 & 65,0 & 34,7 & \\
\hline
\end{tabular}

Note: Data derived from (5) p. 146.

From TABLE 7 it can be seen that the Ejido-Bank, which especially serves the ejido, plays only a modest role (due to lack of funds?). As has been stated already the ejidos urgently require capital investments. It is to be regretted, that credits could not be extended on a larger scale. The reason might be that on many ejidos the managerial skill is not yet such as to utilize credits properly and to an optimal extent.

Credits are only given to ejidos having set up a special credit-association. Only $27 \%$ of the 18.700 ejidos in existence in 1959 had such an association. In 1936 the percentage was 37 ; it gradually decreased.

For 1959 it has been estimated that of the total inputs in agriculture of $11.500 \mathrm{mln}$ pesos, $36 \%$ came from private capital resources of the agriculturists, $3 \%$ from the Government and $61 \%$ from credits. The first source has diminished in recent years; the last one (credits) has increased.

Total agricultural credit in 1959 amounted to about 7 bln pesos of which $16 \%$ was provided by the Ejido Bank, $11 \%$ by other National Banks, $53 \%$ by private Banks and $20 \%$ by other private money lenders (5). 


\section{Appraisel of Land Reform}

It cannot be denied that the agrarian reform has been an important factor in the economic development of the country. It indirectly stimulated enterprise in industry and commercial agriculture.

"The program ended the land monopoly and broke the power of the landed aristocracy that ruled Mexico before the Revolution, it also freed the farm workers from the economic bonds that attached them to the haciendas, and gave them the mobility which brought so many of them to the cities in search of industrial employment" (12). Great progress has been made in agricultural output.

Productivity. From previous figures the following can be derived:

$\begin{array}{llccc} & 1940 & 1950 & 1960 \\ \text { Number of workers in agriculture (mlns) } \ldots \ldots \ldots \ldots \ldots \ldots & 3,8 & 4,9 & 6,0 \\ \text { Gross agricultural product at } 1950 \text {-prices (blns pesos) } \ldots \ldots & 5,0 & 8,9 & 16,0^{1} \\ \text { Agr. product per worker at } 1950 \text {-prices (1000 pesos) } \ldots \ldots & 1,3 & 1,8 & 2,7 \\ \text { Agr. product per worker on ejidos in } 1950 \text { (1000 pesos) } \ldots \ldots & & 1,0^{2} & \end{array}$

(According to EDMUNDo FloRES (6) productivity per capita of economically active population engaged in primary activities rose in the same period from 1900 to 4800 pesos, based on 1960-prices, which figures show a higher increase than calculated above.

Although this doubling of the product per worker looks very satisfactory, it should be taken into account that the gross agricultural product tripled in the same period and that productivity in agriculture is still very low compared with other sectors since $53 \%$ of the working population contributes only $21 \%$ to the national product. On the ejidos production per worker is still much less than the average (in 1950 1000 against 1800 pesos). The value of agricultural and animal production per ha of cultivated area in 1950 amounted to 475 pesos on ejidos as to 740 pesos on private holdings of more than 5 ha (Comparable figures of holdings of 5 ha and less are not at hand).

Although many ejidos are not as productive as private farms (due to smallness of plots, low educational level, poor farming techniques and small capital resources) "ejido farms produce more than $70 \%$ of the tobacco, more than $60 \%$ of the wheat, rice, sesame and henequen, and more than $40 \%$ of the corn, beans, sugarcane, barley, and bananas" (12).

Exports of bananas and henequen for a major part originate from ejidos. Of livestock raising about $40 \%$ is on ejidos.

It seems obvious then that land reform has contributed substantially to the economic development and that raising productivity of ejido farms is important for the whole well-being of the country. The question may be raised however, whether continuation of the current land redistribution program would offer the best results in the long run or whether more emphasis should be laid on alternative ways and means to bring about economic development.

According to what has been said and written about it and also from personal im-

1 Estimate; the 1959 figure was 15,2 .

2 Value of agric. production of ejidos in 1950: 2,5 bln pesos. Number of agric. workers on ejidos in 1950: about $2,5 \mathrm{mln}$.

(derived from Tercer Censo Ejidal, 1950). 
pressions it can be safely said that the landreform has been a success socially, but that economically the results have not been a success altogether. There has been quite some criticism on mismanagement on the side of the Government and "the ejidos were denounced as costly and ill-advised experiments doomed to failure" (7). On the other hand there also has been much praise. People working in ejidos or in close touch with them seem convinced that the ejido-system has done much good and will continue to do so in spite of its shortcomings. In general one gets the impression that the ejido system ought to be a success also because of the great deal of enthousiasm which has gone into it since the revolution. It seems clear that in the beginning the Government, with the revolution going on, could not do otherwise than to give land to the landless in order to ease political unrest. Now after half a century of landreform it would be worth while to examine the situation once more.

Must emancipation of the rural population and social justice prevail or economic development? It is difficult to answer this question, especially for an outsider. The best approach seems to be a synthesis, in other words the strive for economic development and social justice both.

In general it can be said that Mexico is proceeding at a fast rate from "underdeveloped" towards "developed" country and that it is nearing the second stage. In its sustained economic growth however the contribution of agriculture is lagging behind, be it that much progress has been made. Per capita the income especially of ejidatarios and peasants should be raised by all means through increased productivity in order to raise the purchasing power.

What contribution did the ejido-system make to agricultural development and to the overall economic development?

In trying to evaluate the results of the land reform program in economic terms one is hampered by the lack of relevant data. The assumption that the ejido-system did result in economic development seems to have become too much of an "a priori" success.

There has been economic and social development and there has been agricultural development in which the ejido-system played an important role. From the mere fact that a substantial increase of ejido-land coincided with a substantial increase in agricultural production it may not be concluded that the latter is a result of the ejido-system. Increased agricultural production would be the result of any expansion of farmland cultivation. Hence more data are needed on the proportion of ejido-production to overall agricultural production and on input-output relations and final results in ejido-versus private farming.

Some investigations have been - and are being - carried out on a regional base, which offer a better insight than the general data available.

\section{Regional investigations}

In 1956 a comprehensive study has been published of the "Economic District of Celaya", comprising 7 communities in the State of Guanajuato of which the town Celaya is the centre (2).

The investigation relates to 200.000 persons on an area of 275.000 ha. 


\begin{tabular}{|c|c|c|}
\hline & Private farms & Ejidos \\
\hline Agricultural land & $96.000 \mathrm{ha}$ & $106.000 \mathrm{ha}$ \\
\hline Arable land ... & 79.000 & 61.000, \\
\hline of which cultivated & 69.000 & 53.000 \\
\hline Irrigated area & 42.000, & 29.000 \\
\hline Total number of holdings & 2.600 & 8.500 \\
\hline Economically active population & 6.000 & 19.000 \\
\hline of which in agriculture & 5.000 & 17.000 \\
\hline
\end{tabular}

Percentage illiteracy among persons of the age of 12 years and more $\ldots \ldots \ldots \ldots \ldots \ldots \ldots \ldots \ldots \ldots \ldots \ldots \ldots$

Percentage unemployment in man-months of total man

months per category available

Private farms Ejido farms

(Computed from table 67 in (2)).

Investments. Of the investments about $2 / 3$ are fixed capital, $1 / 4$ semi-fixed and $1 / 10$ working capital ("capital circulante").

Private farms Ejido farms

Invested capital per ha cultivated area (in pesos) $\ldots \ldots \quad 5000 \quad 2700$

New investments in 53/54 amounted to $14,9 \mathrm{mln}$ pesos on private farms and only $1,6 \mathrm{mln}$ on ejido farms. Of these amounts it has been computed that 4,9 and $1,2 \mathrm{mln}$ pesos resp. served as replacement and depreciation so that the nett investments were $10 \mathrm{mln}$ pesos on private- and $0,4 \mathrm{mln}$ pesos on ejido farms. As a matter of fact nett investments on the latter were negative with the exception of animal stock. This means that except on animal stock the ejidatarios literally were consuming their resources! (from table 91 in (2)).

It is not surprising that as a result of less favorable conditions production per ha is lower than on private farms.

The following figures show the productivity in pesos per ha for broad types of farming.

\begin{tabular}{|c|c|c|}
\hline Classifications of cultivation & Private farms & Ejidos \\
\hline Intensive farming & 3347 & 1238 \\
\hline Semi intensive farming & 1143 & 958 \\
\hline Semi extensive farming & 524 & 310 \\
\hline Extensive farming & 232 & 142 \\
\hline
\end{tabular}

(table 109 of (2)).

In $53 / 5422,5 \mathrm{mln}$ liter milk was produced (value $14 \mathrm{mln}$ pesos) of which $85 \%$ came from private farms and only $15 \%$ from ejidos. The production per cow was nearly 20001 on private farms and only nearly 11001 on ejidos.

The value of animal production on total private farms was more than 3 times as high as on the ejidos.

As a rough average of the existing wide variation in types of farming and results the following figures give an idea of some of the differences between private farms and ejido farms : 


\section{Private farms Ejido farms}

$\begin{array}{llcc}\text { Area of holding in ha } \ldots \ldots \ldots \ldots \ldots \ldots \ldots & 37,2 & 6,8 \\ \text { Labor in man months } \ldots \ldots \ldots \ldots \ldots \ldots \ldots & 52,61 & 12,8^{1} \\ \text { Capital }(\times 1000 \text { pesos) } \ldots \ldots \ldots \ldots \ldots \ldots \ldots & 53,0 & 5,5 \\ \text { Gross returns }(\times 1000 \text { pesos) } \ldots \ldots \ldots \ldots \ldots & 33,4 & 5,1 \\ \text { Value of resources }(x 1000 \text { pesos }) \ldots \ldots \ldots & 133,6 & 17,9\end{array}$

(from tables 127 and 128 of (2)).

Although the produced figures seem questionable in some cases it may be concluded from the comprehensive study that in general the ejido-farm is inferior to the private farm.

As compared with existing private farms the area per worker on the ejido farms is too small; there is much unemployment; on the ejidos soil and irrigation are in many cases less favorable; the educational level is lower; the use of capital is poor and there are even signs of decapitalization. In general the use of resources and the techniques of farming are less efficient.

The main reasons of this less favorable situation are said to be the weak structure and functioning of the ejido as an organization and the poor educational level of the ejidatarios demonstrated in their inadequate managerial capability.

It seems however, that smallness of holdings, the lack of capital, unemployment and poor use of resources are severe handicaps, aggravated by the apparent lack of alternative occupations especially outside agriculture.

From a study of the Ejido El Mangal (10) on the coastal plain in the state of Veracruz it can also be concluded, that this ejido does not use its resources profitably due to various limiting factors, of which man himself is said to be the principal one. He has a poor educational level and his relations with the outside world and even with his neighbours within the ejido are limited. He feels that he should be self-sufficient. As a member of the ejido he "lacks knowledge regarding his responsibility as a holder of a parcel which is national property, he is ignorant of his legal rights and obligations....."

His income is low and does not enable him to make investments or to improve his working conditions. "He finds himself within a circle that he has been unable thus far to break. He cannot increase his productivity because he cannot invest and he cannot invest becauuse he cannot increase his productivity".

As an example of backward and inefficient working methods it was found that in corn growing $30 \%$ of the time was spent in combating weeds and in the cultivation of beans even $51 \%$.

\section{Conclusions}

From the foregoing orientation (which could not include all factors involved) the following comments may be presented:

1. In their zeal to ease political unrest, restore social justice and develop the rural economy the Mexican Government has energetically taken drastic measures of landreform. It seems however, that due to political urgency no time could be taken

1 The connection with previous figures (p. 85) is not clear. Only a comparatively small part of the ejido-people are employed on private farms. 
for any preparatory measures or planning. There seem to have been no initial studies of the best land-use patterns, types of farming, size of holdings and organization of agricultural production in general. Recently undertaken investigations should be intensified.

2. In the general fervour to do away with the "haciendas" too much has been expected of the splitting up of large holdings and the distribution of lands among the small and landless farmers. This redistribution of land however does not automatically lead to improvements of agriculture or more prosperity for the farmers.

Moreover the question may be raised why a combination of large plantations and medium sized and small holdings should not offer favorable results (11). As a matter of fact experience does indicate favorable results when large-scale plantations exist side by side with small holdings (21).

Finally there is no perfect land tenure system which guarantees agricultural efficiency under all circumstances. "At one time or another all systems have been adequate or inadequate under certain conditions and in certain stages..." (9). So agrarian reform does not need to overthrow existing tenure systems, if only provisions are made for successful adjustments.

3. Too little consideration has been given to optimum size and type of the new holdings in ejidos. "No agrarian reform can remedy a situation where too many cultivators are trying to get a living from too little land" (9). The result has been that especially in the central densely populated regions too many too small holdings have come into being with the accompanying serious disadvantage of unemployment, inefficient farming, lack of capital resources and poor social structure. More attention should therefore be given to allotments of land to undersized holdings.

4. A severe handicap is the lack of alternative opportunities within and outside agriculture. The only way to ease the situation in the overpopulated agricultural regions seems to be the promotion of employment outside agriculture.

5. It has become evident that also in Mexico landreform should apply not only to the way land is held but just as much to the man who works it (9).

The success or failure of an ejido depends largely on its structure and functioning as an organization and therefore on local leadership. Much more emphasis than hitherto should therefore be laid on training for leadership, community development, and on educational, research and extension-work. The generating of self-interest, self activities and self-help among the ejidatarios should rank highest in this approach.

6. Next to this educational work "from within" the Government should expand its activities in such fields as communication and transport, irrigation, credit and marketing in order to create a more favorable agrarian structure "from the outside". Furthermore, since successful implementation of land reform in its wide sense calls for careful coordination and integration of all efforts, it might be advisable to bring about more coordination on the national and regional level.

7. It seems that too much value has been attached to the land tenure aspects and the legal regulations and too little to the creation of opportunities for efficient farming.

Nowadays inefficiency in agriculture cannot any longer be tolerated without national and even international danger. And this applies to all sorts of farms including large estates, small holdings and communal farms (1). Therefore in the land reform program emphasis should be laid more on organization and techniques to promote efficient farming than on legal status. 
In this context it should be mentioned that upper and lower limits for the size of holdings in any land redistribution program have been advocated (19). Upper and lower limits "should give ample leeway to diversity of farm sizes which would suit the needs of various types of families and managerial skills", provided there is enough land. Therefore it might be worth while to consider, and eventually work out, an agrarian structure based on a co-existence and collaboration of efficient large scale, medium and small farming units. In this pattern the ejido system may for the time being fit in very well. The ejidatarios could on the one side profit in making use of improved farming techniques or in sharing facilities of transportation, communication, or irrigation and marketing and on the other hand render services as laborers, tractor drivers, cart-drivers, traders, etc. If well cared for by the authorities this situation might lead to more diversification and integration of the rural economy, which would result in more alternative opportunities, more commercialization and increased productivity.

With a developing agrarian structure, increasing commercialization and diversification and accompanying inidividualization the time may come for further changes in the land tenure structure. Communal ownership might gradually have to give way to individual ownership, which usually provides a better basis for modern commercialized farming.

Also in pre-war Indonesia and post-war Africa agricultural extension and new agricultural settlement schemes led to changes from communal to individual ownership of lands.

8. As the development of agriculture depends on rural development and has to be integrated into overall development, more attention should be given to integrated planning of socio-economic development aiming at a well distributed increase of per capita income and a sound social structure.

Since an annual increase of per capita income of $3 \%$ is being considered the minimum for rapid growth (18), the present rate of growth of per capita income of $2 \%$ in Mexico seems to be moderate. However a more favorable distribution of income to the benefit of the rural population seems to be still more urgent than a further rapid total increase.

9. There is a growing recognitition of the need for more investigations in rural economics. Various institutions carry out economic studies in specific fields. Special mentioning deserve the "Instituto Nacional de Investigaciones Agricolas", which is partly financed by the Rockefeller Foundation, and the "Centre de Investigaciones Agrarias", partly financed by Banks dealing with Agriculture, and partly by the Ministry of Water-Resources.

Since Land Reform is ultimately aiming at socio-economic development and the economic results have not yet been satisfactory so far, it seems advisable to strengthen and bring together the at present scattered efforts into one organization which should guide and coordinate all research work in rural economics.

Publication of the studies would offer valuable information for those concerned with agrarian reform also in other countries.

At the Inter American Conference at Punta del Este in August, 1961 agrarian reform received much attention. The result will be, that development plans will be drawn up which may help in guiding and accelerating a well balanced development.

It is to be hoped that in coming years the statement in "The State of Food and Agriculture 1961", that the ejido system "has yet far to go before it can be said 
to have justified itself in terms of efficient farming and a high standard of living for the farmer" can be modified into a more optimistic one.

\section{REFERENCES}

(1) BINNS, Sir BERNARd O.

1955 Plantations and other centrally operated estates. F.A.O., Rome.

(2) Castilloo, Carlos
Manuel

1956 La Economia Agricola en la region del Bajio. Problemas

(3) Defects

(4) Documentation

1951 Defects in agrarian structure as obstacles to economic development. UNO, New York.

1961 Documentation on Mexican agricultural economy. The XI Intern. Conference of agr. economists in Cuernavaca Mexico, August 1961.

(5) Fernandez Y FernanDEZ, RAMON, y RICARDo Acosta

(6) Flores, Edmundo

1961 Politica Agricola. Fondo de Cultura Economica. Mexico Buenos Aires.

1961 Tratado de Economia Agricola. Fondo de Cultura Eco-

1954 People in Ejido. F. A. Praeger, New York.

(7) INFIELd, HeNRIK F., and KOKA FrEIER

(8) Informe

(9) J ACOBY, E. H.

(10) JIMENEZ, LEOB ARDO

(11) Joosten, J. H. L.

(12) Land

(13) Mexico

(14) Mexico

1954 People in Ejido. F. A. Praeger, New York.

1960 Informe Annual 1960, Banco de Mexico.

1953 Inter-relationship between agrarian reform und agricultural Development. FAO Land Tenure Study.

1961 El Mangal, Una población ejidal de la costa veracruzana. Chapingo. March 1961.

1959 Landhuishoudkundige aspecten van herverdelingen $\operatorname{van}$ grootgrondbezit. Inaugural Speech, Wageningen, 1959.

1961 Land distribution in Mexico. Foreign Agric. Service, U.S. Dept. of Agric., March 1961.

1959 Mexico en Cifras. Secretaria de Industria y Comercio, direccion general de Estadistica, Mexico.

1960 Mexico 1960; Facts, figures, trends (prepared and edited by the Banco Nacional de Comercio Exterior, 1960).

(15) Navarkete, J. Patino

1961 Outlook for the agricultural economy of Mexico. Paper read by the Undersecretary of Agriculture at the XI International Conference of agricultural economists held in Cuernavaca - Mexico, August 1961.

(16) Progress

(17) RenNe, Ronald R.

1954, 1956 Progress in land reform. U.N. New York.

(18) Report

1958 Land economics. Harper \& Brothers, New York.

1961 Report of the expert working group on social aspects of economic development in Latin America (Dec. 1960). Econ. Bulletin for Latin America. March 1961.

(19) Schickele, Rainer

1957 Resettlement problems and policies. Neth. J. agr. Sci. $239-254$.

(20) State

(21) Tempany, Sir Harold, and D. H. GRIST

(22) Whetten, Nathan L.

1961 The state of food and agriculture; Chapter III: Land reform and institutional change. FAO, Rome.

1960 An introduction to tropical agriculture. Longmans Green, London.

1948 Rural Mexico. The University of Chicago Press, Illinois, Chicago. 